Revista Brasil. Bot., V.27, n.4, p.639-640, out.-dez. 2004

\title{
Lectotypifications in Ditassa R.Br. (Apocynaceae: Asclepiadoideae)
}

\author{
TATIANA U.P. KONNO ${ }^{1,2}$ and MARIA DAS GRAÇAS L. WANDERLEY ${ }^{1}$
}

(received: August 28, 2003; acceoted: July 1, 2004)

\begin{abstract}
Lectotypifications in Ditassa R. Br. (Apocynaceae: Asclepiadoideae)). As results of a revision of the Brazilian species of Ditassa, lectotypes for D. endoleuca Schltr., D. pauciflora Decne. and D. ramosa E. Fourn. (=D. blanchetii Decne.) are designated.
\end{abstract}

Key words - Ditassa, lectotypes, Neotropics, nomenclature

RESUMO - (Lectotipificações em Ditassa R. Br. (Apocynaceae: Asclepiadoideae)). Como resultados da revisão das espécies brasileiras de Ditassa, lectótipos para D. endoleuca Schltr., D. pauciflora Decne. e D. ramosa E. Fourn. (=D. blanchetii Decne.) são designados.

Palavras-chave - Ditassa, lectótipos, Neotrópicos, nomenclatura

\section{Introduction}

Ditassa R. Br. is a neotropical genus of Asclepiadoideae (Apocynaceae) with approximately 115 species and one of the richest genera of Asclepiadoideae in Brazil. Since Brown (1810) described Ditassa, the genus has never received a formal revision. Most of the names had been established before 1950. Since then, the nomenclature and taxonomy of Ditassa have been treated in diverse papers, especially by Fontella-Pereira (1965, 1979a, 1979b, 1989, 1993), Fontella-Pereira et al. (1995), Fontella-Pereira \& Schwarz (1981) among others and, more recently by Rapini et al. (2001), Fontella-Pereira \& Konno (2002) and Rapini (2002).

The genus is usually recognized by subaxillary umbelliform cymes and flowers with a corona compound of two segments, in which outer segments are united to each other at least at the base. Based on molecular evidences, Ditassa is clearly a polyphyletic group (Rapini et al. 2003), demanding new realignments.

Apart from a phylogenetic discussion, the genus is still in need of some basic nomenclature work. In order to complete the ongoing monograph of Ditassa, the types of Brazilian and non-Brazilian species were examined. Some of these species are being lectotypified in this work.

\section{Material and methods}

Type collections of the following herbaria were examined: BM, BR, C, F, G, HB, K, MBM, MO, NY, P, R, RB, SP, SPF, W, UPS and US (acronyms according to Holmgren \&

\footnotetext{
1. Instituto de Botânica de São Paulo, Av. Miguel Estéfano 3687, 04301-012 São Paulo, Brazil.

2._Corresponding author: tkonno@uol.com.br
}

Holmgren 2003). Additional information on the types not presented in the original publication are added.

\section{Results and Discussion}

1. Ditassa ramosa E. Fourn. in Mart., Fl. bras. 6(4):246. 1885. Lectotype, designated here: BRAZIL, "ad Bahia", s.d., J.S. Blanchet s.n. (P 00140190!; isolectotypes G, MO, W!). Other syntypes: BRAZIL, "ad Ilheos, prov. Bahia", Luschnath 1314 (BR!); "Rio de Janeiro", Glaziou 11202 (P!, K!).

Ditassa ramosa is known only by the type collection. It was described based on three specimens, two from Bahia State (Luschnath 1314 and Blanchet s.n.) and one from State of Rio de Janeiro (Glaziou 11202). The material collected by Blanchet $(\mathrm{P})$ agrees perfectly with the protologue and was selected as the lectotype of $D$. ramosa.

The similarities between Ditassa ramosa and $D$. blanchetii are numerous and D. ramosa is a synonym of D. blanchetii. Ditassa hispida is the most similar species to $D$. blanchetii but differs in having hispid indument covering entirely the stem (vs. bilateral indument in $D$. blanchetii).

2. Ditassa endoleuca Schltr., Bot. Jahrb. Syst. 37:612. 1906. Lectotype, designated here: "Ecuador, in fruticetis prope Loya [Loja]", 2,000-2,300 m.s.m., s.d., F.C. Lehmann 7886 (K!; isolectotype US!; original syntype at B destroyed). Other syntype: "Columbia, in fruticetis prope Popayan", 1,800-2,000 m.s.m., s.d., F.C. Lehmann 4843 (B destroyed, F!, K!).

Ditassa endoleuca occurs in Colombia, Ecuador and Peru, on high elevations (1,600-2,500 m.s.m.) and 
xerophytic habitats. The stem is densely tomentose and glaucous. The oblong leaves are also indumented and have strongly revolute margins. Examination of other Ditassa collections from Colombia highlighted the relation of $D$. endoleuca with $D$. caucana Pittier. However, further comments could only be made when the whole diversity of Ditassa in Neotropics has been evaluated.

3. Ditassa pauciflora Decne. in A. DC., Prodr. 8:577. 1844. Lectotype, designated here: "In Guiana Angl., Piraro", s.d., Schomburgk 359 (K!; isolectotypes BM!, G, LE, P!). Other syntype: Ibidem, Schomburgk 770 (BM!, G, K!, LE, P!).

= Ditassa divaricata Turcz., Bull. Soc. Imp. Naturalistes Moscou 25(2):317. 1852. Type: "Guiana Britannica, 1837, Schomburgk 770 (LE), nom. superfl.

The syntypes Schomburgk 770 and 359 at K, BM and $\mathrm{P}$ are in conformation with the original description. However, Turczaninow (1852) placed Schomburgk 770 (LE) under a new species $D$. divaricata Turcz. with the allegation that this material was totally different from what Decaisne (1844) named as D. pauciflora. On the other hand, Turczaninow (1852) confirmed the identity of Schomburgk 359 as D. pauciflora. In spite of being a richer material, Schomburgk 770 is a dubious collection, hence it is conclusive that Schomburgk 359 should be assigned as the lectotype of D. pauciflora.

Acknowledgements - We are grateful to Fapesp for funding this research and the Margaret Mee Foundation which sponsored the visit of the first author to the European institutions. We also would like to thank to the Royal Botanic Gardens, Kew for the facilities and support. Special thanks to Fabio de Barros, Jefferson Prado and the anonymous reviewers for the corrections and suggestions to the paper.

\section{References}

FONTELLA-PEREIRA, J. 1965. Contribuição ao estudo das Asclepiadaceae brasileiras, II. Sellowia 17:61-76.

FONTELLA-PEREIRA, J. 1979a. Contribuição ao estudo das Asclepiadaceae brasileiras, XII. Novos sinônimos e uma nova combinação. Bradea 3:5-9.
FONTELLA-PEREIRA, J. 1979b. Contribuição ao estudo das Asclepiadaceae brasileiras, XIII. Ditassa tomentosa (Decne.) Fontella, uma nova combinação. Boletim do Museu Botânico Municipal, Curitiba 39:1-4.

FONTELLA-PEREIRA, J. 1989. Contribuição ao estudo das Asclepiadaceae brasileiras, XXIII. Considerações sobre Ditassa parva (Silveira) Fontella e espécies correlatas. Eugeniana 16:19-27.

FONTELLA-PEREIRA, J. 1991. Asclepiadaceae brasiliensis, IX. Novos táxons. Bradea 5:478.

FONTELLA-PEREIRA, J. 1993. Contribuição ao estudo das Asclepiadaceae brasileiras, XXV. Duas espécies novas dos campos rupestres. Bradea 6:237-242.

FONTELLA-PEREIRA, J. \& KONNO, T.U.P. 2002. Estudos em Asclepiadaceae, XXXI. Duas novas espécies de Ditassa para o Brasil. Bradea 8:319-322.

FONTELLA-PEREIRA, J. \& SCHWARZ, E.A. 1981. Estudos em Asclepiadaceae, XIV. Novos sinônimos e uma nova combinação. Boletim do Museu Botânico Municipal, Curitiba 50:1-14.

FONTELLA-PEREIRA, J., VALENTE, M.C. \& SILVA, N.M.F. 1995. Flora da Serra do Cipó, Minas Gerais: Asclepiadaceae. Boletim de Botânica, Universidade de São Paulo 14:131-179.

FOURNIER, E. 1885. Asclepiadaceae: Ditassa. In Flora brasiliensis (C.F.P. Martius \& A.G. Eichler, eds.), F. Fleischer, Lipsiae, v.6, pars 4, p.237-257.

HOLMGREN, P.K. \& HOLMGREN, N.H. 2003. On-line edition of Index Herbariorum. New York Botanical Garden web site, Bronx. (http://www.nybg.org/bsci/ih/).

RAPINI, A. 2002. Six new species of Ditassa R. Br. from the Espinhaço Range, Brazil, with notes on generic delimitation in Metastelmatinae (Apocynaceae Asclepiadoideae). Kew Bulletin 57:565-583.

RAPINI, A., CHASE, M.W., GOYDER, D.J. \& GRIFFITHS, J. 2003. Asclepiadeae classification: evaluating the phylogenetic relationships of New World Asclepiadoideae (Apocynaceae). Taxon 52:33-50.

RAPINI, A., MELLO-SILVA, R. \& KAWASAKI, M.L. 2001. Asclepiadadoideae (Apocynaceae) da Cadeia do Espinhaço de Minas Gerais, Brasil. Boletim de Botânica, Universidade de São Paulo 19:55-169.

TURCZANINOW, S. 1852. Asclepiadeae quaedam hucusque indescriptae. Bulletin de la Societe Imperiale des Naturalistes de Moscou 25(2): 310-325. 